\title{
Geochemistry of Granites from Chail Group of Garhwal Region, Lesser Himalaya, NW India
}

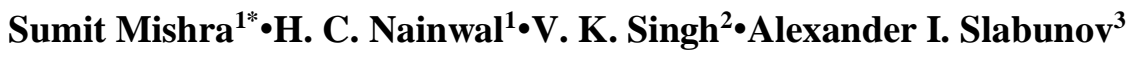 \\ ${ }^{1}$ Department of Geology, H N B Garhwal University, Srinagar-Garhwal, Uttarakhand, India \\ ${ }^{2}$ Department of Geology, Bundelkhand University, Jhansi, Uttar Pradesh, India \\ ${ }^{3}$ Institute of Geology, Karelian Research Centre, Russian Academy of Sciences, Petrozavodsk, Russia \\ *Corresponding Author Email Id: smpsgeo@gmail.com
}

Received: 31.7.2021; Revised: 21.11.2021; Accepted: 29.11.2021

OSociety for Himalayan Action Research and Development

\begin{abstract}
Paleoproterozoic granites are well exposed in the Chail group of Garhwal region, Lesser Himalaya crystalline sequences (LCHS). These granites are less studied in terms of geochemical classification and tectonic settings. In the present work, we carried out the geochemical analysis of granites of the Chail group from the Chirbatiya-Khal and Ghuttu areas. All the samples have high $\mathrm{SiO}_{2}\left(73.24-79.1\right.$ wt \%), $\mathrm{Al}_{2} \mathrm{O}_{3}(11.2-12.95$ wt \%), $\mathrm{K}_{2} \mathrm{O}$ (3.8-5.9 wt \%) and low $\mathrm{P}_{2} \mathrm{O}_{5}\left(0.11-0.24\right.$ wt \%), $\mathrm{CaO}\left(0.21-1.02\right.$ wt \%), and $\mathrm{Na}_{2} \mathrm{O}$ (2.2-3.03 wt \%; exceptionally low in one sample, that is 0.009 wt \%) contents. The $\mathrm{A} / \mathrm{CNK}$ values for the samples are range from 1.19 to 2.91, characteristic of S-type granites. REE patterns for these granites are moderately fractionated with an average $(\mathrm{La} / \mathrm{Yb})_{N^{\sim}} \sim 8.21$ and europium anomaly $\left(\mathrm{Eu} / \mathrm{Eu}^{*}\right) \sim 0.15$. The tectonic settings of the studied granite suggest that they are formed in syn-collision tectonic environments.
\end{abstract}

Keywords: Granites, Himalaya, geochemistry, Paleoproterozoic, Garhwal Himalaya

\section{Introduction}

Granites are the most abundant rocks in the Earth's crust. Therefore, understanding the origin of the Earth requires a thorough understanding of the evolution and reworking of the upper continental crust. Granites have a vast range of mineral composition, geochemistry, petrogenesis, and tectonics, as evidenced by extensive studies undertaken around the world. In general, it is now believed that a significant number of granites, such as those seen along active continental margins, can result from fractional crystallization of basaltic magma. In addition, under variable temperature and pressure conditions, partial melting of crustal protoliths during regional metamorphism in orogenic collisions also creates varied granites.
This paper aims to present the whole-rock geochemistry from Chail group granites in the Garhwal region of LHCS. We suggest that these Paleoproterozoic granites are S-type in origin and formed in syn-collision tectonic settings, based on their geochemical characteristics.

\section{Geological background}

In the $2400 \mathrm{~km}$ long Himalayan belt, four primary tectonic zones accrete from south to north: 1) Sub-Himalaya (SH); 2) Lesser Himalaya (LH); 3) Higher Himalayan Crystalline (HHC); and 4) Tethyan Himalaya (TH) (Heim \& Gansser, 1975). (Fig. 1a). The $\mathrm{SH}$, which is made up of Miocene to Pleistocene molasses and Himalayan sediments, thrusts over the Indo-Gangetic 
plane along the Main Frontal Thrust (MFT) (Thakur, 1992). Paleoproterozoic to lower Cambrian rocks make up the LH sequence, which is thrust above the $\mathrm{SH}$ along the Main Boundary Thrust (MBT) (Valdiya, 1980). The Main Central Thrust (MCT), a north-dipping intra-continental shear zone with an inverse metamorphic gradient, is one of the most important tectonic features in the Himalayas (Metcalfe, 1993). MCT distinguishes LH from HHC. The HHC is made up of medium- to high-grade metamorphic stages ranging from greenschist to upper amphibolite facies (Thakur, 1992), as well as Ordovician (ca. 485-440 Ma) and early Miocene (ca. $22 \mathrm{Ma}$ ) granites.

The study area is constituted by granite, quartzite, schist, gneisses and meta-basic rocks (Fig. 1b). The undeformed granite exposed around Chirbatiya-Khal area is considered as Bhatwari (= Chail/ Ramgarh) group (Valdiya
1980; Saklani et.al., 1991). This rock unit has sheared up to several meters having brittle ductile deformation (mainly Indian plates basement rocks medium to high metamorphic grade) consider as characteristics of MCT-III zone in the Lesser Himalayan sequence. The rocks of Chail group are tectonically separated by Chail thrust (MCT-III) with massive white quartzite of the Garhwal group towards south (Valdiya 1980; Saklani et.al., 1991; Singh et.al., 1998).

The granites, in the study area, generally show porphyritic texture with abundance of feldspar crystals. Large tourmaline crystals can be observed in the Chirbatiya-Khal granites (Fig. 3a). Muscovite and biotite are also present in the granites. Granites from Ghuttu area are also shows porphyritic characteristics (Fig. $3 b)$. At some places, boudins of quartz can also be observed.

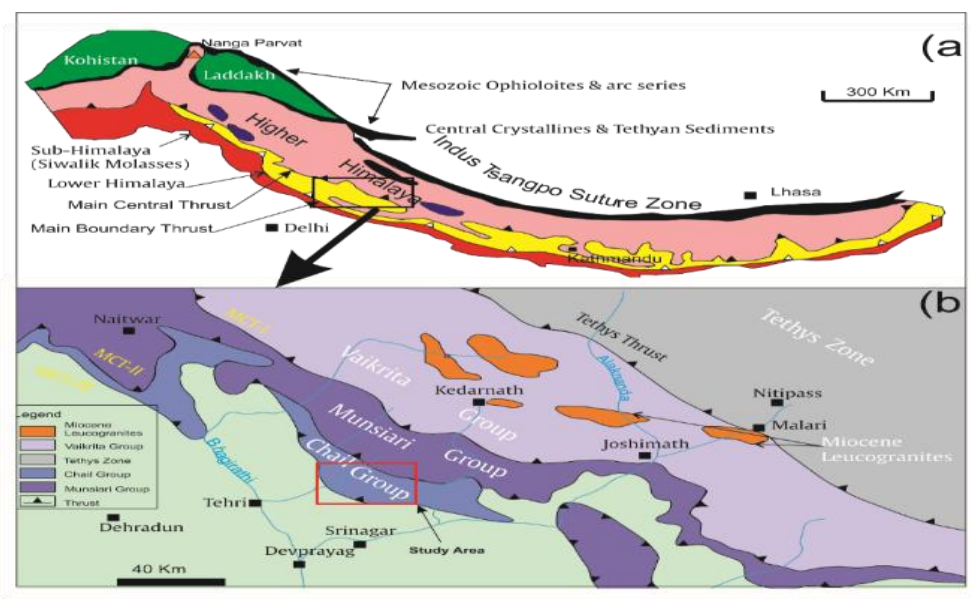

Fig. 1 (a) General tectonic map of Himalaya after Gansser (1964), and (b) General tectonic map of Garhwal Himalaya after Valdiya (1980), MCT-I, II, III after; Saklani et.al., 1991). 


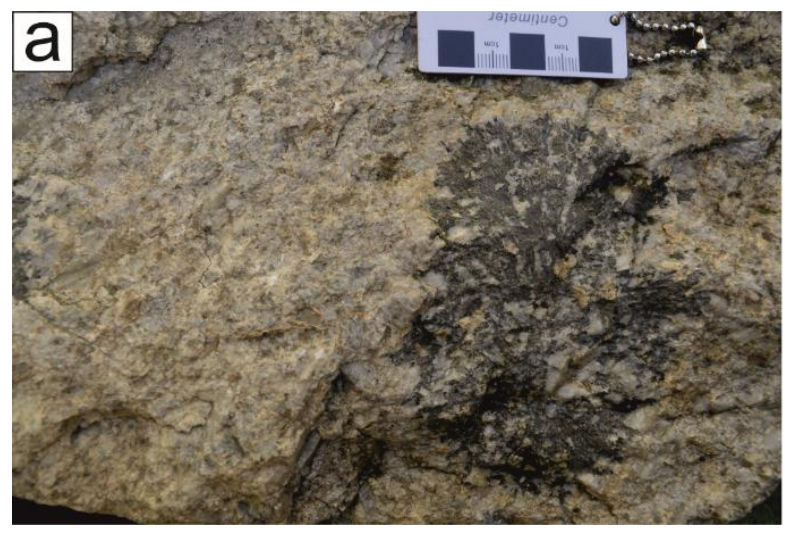

Fig. 2 Photographs of granites from the study area (a) Chirbatiya-Khal granites, a big tourmaline crystal can be seen; (b) Ghuttu granites.

\section{Materials and Methods}

We collected granite rocks from the Chirbatiya-Khal and Ghuttu area of the Garhwal region for geochemical analysis (Fig. 2). Table 1 presents the geochemistry of the granites. The Testing and Matter Analysis Centre, Institute of Geology, KarRC, RAS, Petrozavodsk, Russia, analyzed the chemical composition of the rocks using ICP-MS X Series 2 (Thermo Ficher Scientific, Massachusetts, USA). Svetov et.al., (2015) and Singh and Slabunov (2015) outline the methods and precision in depth which is followed for the analysis. To determine the amounts of rock-forming elements, sample powder was melted with sodium carbonate and then leached with dilute hydrochloric acid. The percentage of $\mathrm{SiO}_{2}$ in the final solution was calculated using the gravimetric technique after it was precipitated with gelatin. The concentrations of $\mathrm{Al}, \mathrm{Fe}, \mathrm{Ca}$, and $\mathrm{Mg}$ in the solution were then estimated complexometrically. At the same time, Ti and $P$ concentrations were estimated photometrically. The allowable variation between the findings of two parallel estimations, which does not exceed 0.7 percent for $\mathrm{Si}, 0.5$ percent for $\mathrm{Al}, \mathrm{Fe}, \mathrm{Ca}$, and $\mathrm{Mg}$, and 0.3 percent for $\mathrm{Ti}$ and $\mathrm{P}$, was used to determine calculation accuracy.

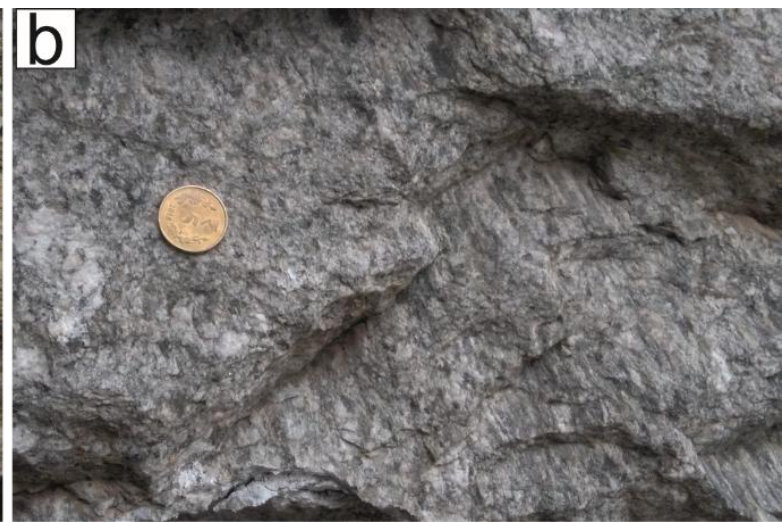

\section{Results}

The K-rich granites from Chirbatiya-Khal and Ghuttu area are mostly calc-alkaline in nature classified as granite in Total alkali silica (TAS) diagram, Middlemost (1994) (Fig. 3a). The normative feldspar classification diagrams [Albite (Ab)-Orthoclase (Or)-Anorthite (An), O'Connor, 1965 and Barker, 1979] indicate that the sample falls in granite field (Fig. 3b). In granitoids $\mathrm{Na}_{2} \mathrm{O}$ is low and varies from 2.2 to $3.3 \mathrm{wt} . \%$ (exceptionally low in one sample, that is $0.009 \mathrm{wt} \%$ ), and $\mathrm{K}_{2} \mathrm{O}$ content varies from 3.8 to 5.9 wt.\%. The $\mathrm{Al}_{2} \mathrm{O}_{3}$ content varies from 11.2 to $12.95 \mathrm{wt} . \%$. The rocks are highly rich in $\mathrm{SiO}_{2}$ having range from 73.25 to 79.1 wt.\%. Alumina content $\left(\mathrm{Al}_{2} \mathrm{O}_{3}\right.$ : Avg. 11.89 wt.\% in the granitoids is greater than the total alkalies $\left(\mathrm{Na}_{2} \mathrm{O}+\mathrm{K}_{2} \mathrm{O}\right.$ : Avg. 7.37 wt. \%), the Titania $\left(\mathrm{TiO}_{2}\right)$ content in the granitoids is low ranging from 0.1 to $0.34 \mathrm{wt} . \%$. The granites belong to high-K calc alkaline magma series, with mostly peraluminous in nature.

The samples are enriched in LREE and moderately depleted HREE along with a pronounced negative $\mathrm{Eu}$ anomaly $\left(\mathrm{Eu} / \mathrm{Eu}^{*}=\right.$ normalized rare earth element distribution pattern (Boynton, 1984) is low to high fractionated $\mathrm{La}_{N} / \mathrm{Lu}_{\mathrm{N}}=(2.23$ to 22.88$)$. A primitive mantle normalized (Sun and McDonough, 1995) multi-element diagram (Fig. 4b) showed a wide range in the concentration of the trace elements. Most of the samples show enrichment of large-ion lithophile elements (LILE) but depletion of $\mathrm{Nb}$, and Ti (McDonough and Sun, 1995). 0.06 to 0.31 ) (Fig. 4a). The chondrite 
Table 1 Major, trace and rare earth elements (in ppm) for the analyzed sample of granites

\begin{tabular}{|c|c|c|c|c|c|c|}
\hline Sample & HM-18-11 & HM-18-13a & HM-18-13b & HM-18-14 & HM-18-16 & HM-18-17 \\
\hline Locality & Chirbatiyakhal & Chirbatiyakhal & Chirbatiyakhal & Chirbatiyakhal & Ghuttu & Ghuttu \\
\hline $\mathrm{SiO}_{2}$ & 79.1 & 73.65 & 75.02 & 74.9 & 75.16 & 73.24 \\
\hline $\mathrm{TiO}_{2}$ & 0.12 & 0.11 & 0.11 & 0.13 & 0.12 & 0.34 \\
\hline $\mathrm{Al}_{2} \mathrm{O}_{3}$ & 11.7 & 12.3 & 11.2 & 11.94 & 12.95 & 11.3 \\
\hline $\mathrm{Fe}_{2} \mathrm{O}_{3}$ & 0.1 & 0.37 & 0.52 & 0.27 & 0.07 & 0.78 \\
\hline $\mathrm{FeO}$ & 0.28 & 1.14 & 1 & 0.86 & 0.14 & 1.14 \\
\hline $\mathrm{MnO}$ & 0.004 & 0.028 & 0.031 & 0.017 & 0.01 & 0.029 \\
\hline $\mathrm{MgO}$ & 2.4 & 1.45 & 1.54 & 1.63 & 1.6 & 1.78 \\
\hline $\mathrm{CaO}$ & 0.21 & 1.022 & 0.72 & 0.72 & 0.58 & 1.57 \\
\hline $\mathrm{Na}_{2} \mathrm{O}$ & 0.009 & 3.03 & 2.2 & 2.6 & 3.56 & 2.34 \\
\hline $\mathrm{K}_{2} \mathrm{O}$ & 3.8 & 5.27 & 5.9 & 5.5 & 4.47 & 5.59 \\
\hline $\mathrm{P}_{2} \mathrm{O}_{5}$ & 0.17 & 0.24 & 0.19 & 0.2 & 0.11 & 0.21 \\
\hline $\mathrm{H}_{2} \mathrm{O}$ & 0.26 & 0.1 & 0.12 & 0.15 & 0.35 & 0.3 \\
\hline LOI & 1.7 & 1.2 & 1.4 & 1.07 & 0.83 & 1.34 \\
\hline Total & 98.153 & 98.71 & 98.551 & 98.917 & 99.12 & 98.619 \\
\hline $\mathrm{FeO}_{\text {Total }}$ & 0.38 & 1.47 & 1.47 & 1.10 & 0.21 & 1.84 \\
\hline $\mathrm{A} / \mathrm{CNK}$ & 2.91 & 1.32 & 1.27 & 1.35 & 1.50 & 1.19 \\
\hline $\mathrm{P}$ & 615.90 & 884.40 & 645.40 & 700.10 & 557.40 & 563.50 \\
\hline $\mathrm{Ti}$ & 680.50 & 594.50 & 587.20 & 437.70 & 166.00 & 1627.00 \\
\hline $\mathrm{Rb}$ & 428.10 & 697.70 & 835.80 & 606.30 & 247.80 & 457.70 \\
\hline $\mathrm{Sr}$ & 3.95 & 12.28 & 8.49 & 10.98 & 33.16 & 55.41 \\
\hline $\mathrm{Y}$ & 37.70 & 47.63 & 12.77 & 29.80 & 15.47 & 32.72 \\
\hline $\mathrm{Zr}$ & 73.42 & 107.20 & 2.76 & 70.01 & 0.96 & 1.57 \\
\hline $\mathrm{Nb}$ & 12.44 & 18.40 & 17.31 & 13.97 & 5.07 & 13.49 \\
\hline Cs & 23.12 & 34.53 & 29.47 & 13.29 & 4.67 & 21.33 \\
\hline $\mathrm{Ba}$ & 35.93 & 38.04 & 25.96 & 51.01 & 67.51 & 258.00 \\
\hline $\mathrm{La}$ & 10.90 & 19.14 & 15.39 & 18.59 & 4.52 & 40.34 \\
\hline $\mathrm{Ce}$ & 24.11 & 40.02 & 28.90 & 42.34 & 8.73 & 63.99 \\
\hline $\operatorname{Pr}$ & 3.08 & 5.05 & 3.56 & 4.88 & 1.21 & 7.80 \\
\hline $\mathrm{Nd}$ & 11.26 & 17.23 & 13.33 & 15.93 & 4.23 & 29.73 \\
\hline $\mathrm{Sm}$ & 2.99 & 4.53 & 3.67 & 4.26 & 1.81 & 6.66 \\
\hline $\mathrm{Eu}$ & 0.27 & 0.16 & 0.07 & 0.11 & 0.06 & 0.63 \\
\hline $\mathrm{Gd}$ & 4.40 & 5. & 3.20 & 4.45 & 1.57 & 5.86 \\
\hline $\mathrm{Tb}$ & 1.01 & 1.34 & 0.63 & 0.98 & 0.49 & 1.16 \\
\hline Dy & 6.45 & 8.34 & 3.22 & 5.72 & 3.13 & 6.44 \\
\hline Ho & 1.25 & 1.57 & 0.48 & 1.03 & 0.55 & 1.09 \\
\hline Er & 3.11 & 3.95 & 0.86 & 2.46 & 1.61 & 2.74 \\
\hline $\mathrm{Tm}$ & 0.42 & 0.54 & & 0.33 & 0.25 & 0.34 \\
\hline $\mathrm{Yb}$ & 2.48 & 3.07 & 0.53 & 1.93 & 1.77 & 1.90 \\
\hline $\mathrm{Lu}$ & 0.29 & 0.37 & 0.07 & 0.24 & 0.21 & 0.21 \\
\hline $\mathrm{Ta}$ & 2.51 & 3.37 & 2.64 & 2.38 & 1.13 & 1.36 \\
\hline $\mathrm{Pb}$ & 6.05 & 17.76 & 26.91 & 18.66 & 45.94 & 45.63 \\
\hline Th & 24.48 & 29.68 & 31.11 & 21.99 & 10.20 & 31.85 \\
\hline U & 4.83 & 2.93 & 3.94 & 9.02 & 6.80 & 4.15 \\
\hline$\Sigma$ REE & 72.01 & 111.15 & 73.90 & 103.24 & 30.13 & 168.86 \\
\hline $\mathrm{Eu} / \mathrm{Eu}^{*}$ & 0.23 & 0.1 & 0.06 & 0.08 & 0.11 & 0.31 \\
\hline \multirow{4}{*}{\multicolumn{3}{|c|}{$\begin{array}{l}\text { It is noted that the studied granites are } \\
\text { characterized by } \mathrm{Ba} \text { and } \mathrm{Sr} \text {-poor, while } \mathrm{Rb} \text {, } \\
\mathrm{Th}, \mathrm{U} \text {, and } \mathrm{Pb} \text { are enriched. The negative } \mathrm{Nb} \\
\text { anomalies and a positive } \mathrm{Pb} \text { anomaly are }\end{array}$}} & \multicolumn{4}{|c|}{ magma generation. While, Miller et.al., (2000) } \\
\hline & & & \multicolumn{4}{|c|}{ discard subduction-related magmatism, and } \\
\hline & & & \multicolumn{4}{|c|}{ also suggested no clear evidence exist for } \\
\hline & & & \multicolumn{4}{|c|}{$\begin{array}{l}\text { collision-related crustal thickening and/or } \\
\text { deformation. }\end{array}$} \\
\hline
\end{tabular}



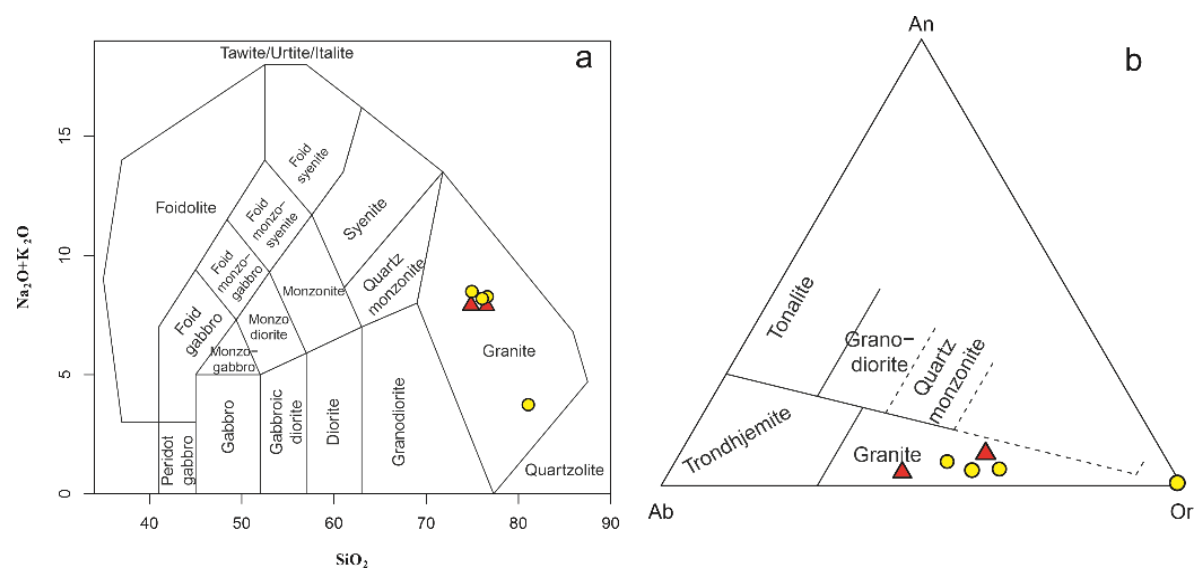

Fig. 3. Classification diagram (a) TAS diagram after Middlemost (1994) (b) Feldspar Triangle after O'Connor (1965).
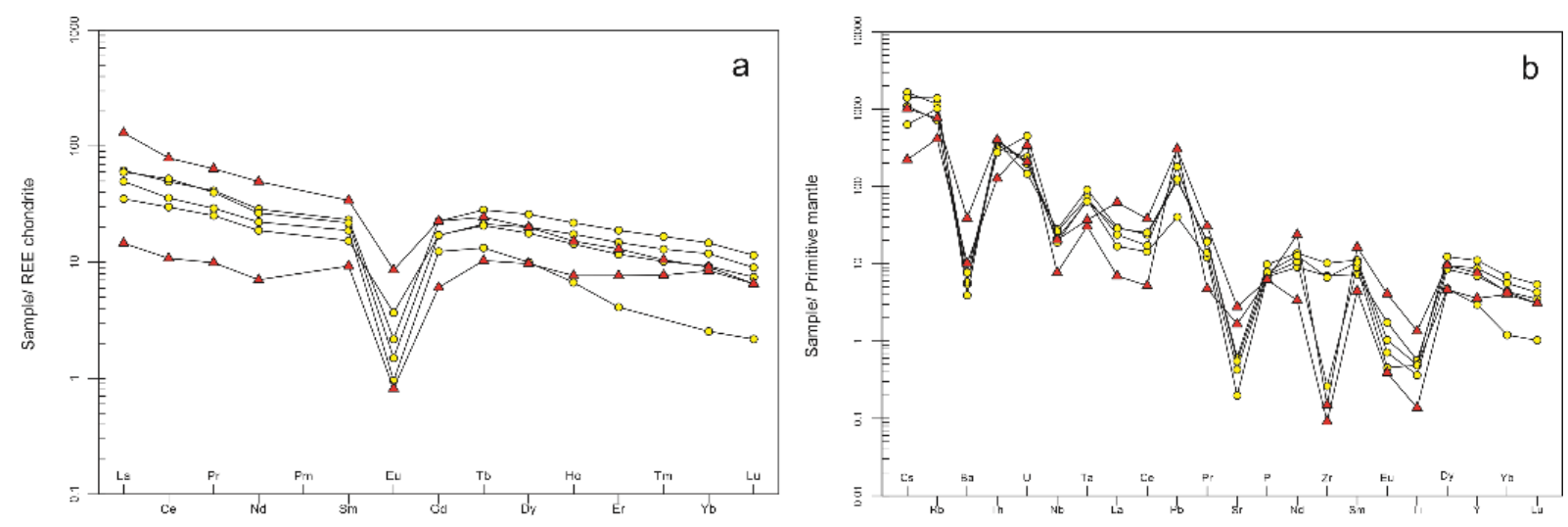

Fig. 4 (a) REE plot after Boynton 1984 (b) Primitive mantle plot after McDonough and Sun (1995).
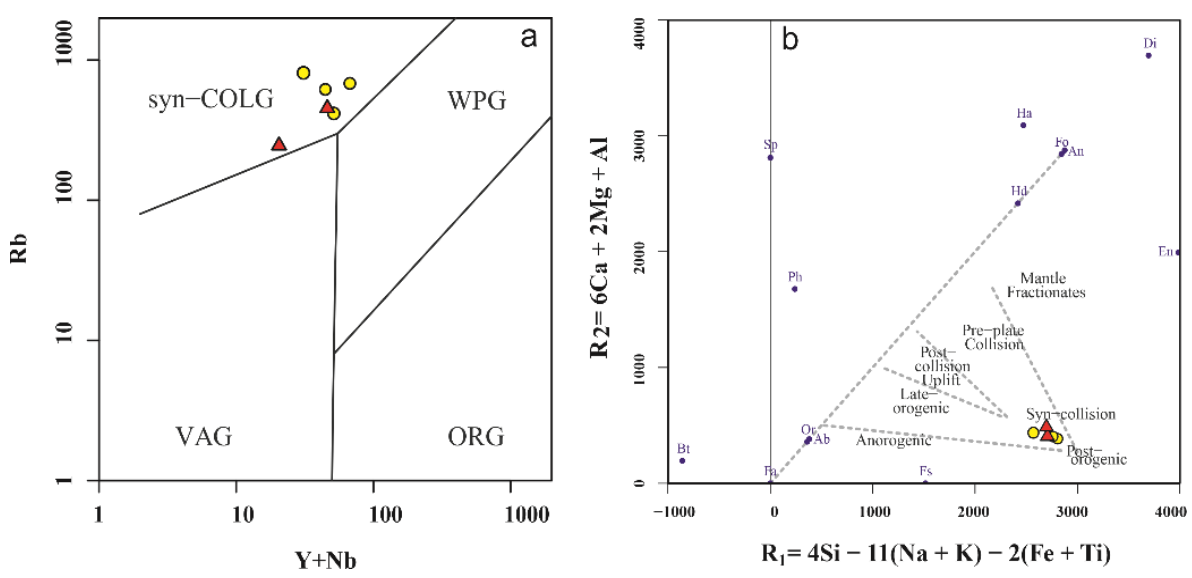

Fig. 5(a) $\mathrm{Rb}$ vs. $\mathrm{Y}+\mathrm{Nb}$ tectonic discrimination diagram after Pearce et.al., 1984 (b) tectonic discrimination diagrams after Batchelor and Bowden (1985).

In the $\mathrm{Yb}+\mathrm{Ta}$ versus $\mathrm{Rb}$ discrimination mostly plot within the syn-collision granite diagram of Pearce et.al., (1984), the granites fields (Fig. 5a). The R1 - R2 $\left[\mathrm{R} 1=4 \mathrm{Si}^{4+}\right.$ 
$11\left(\mathrm{Na}^{+}+\mathrm{K}^{+}\right) \quad 2\left(\mathrm{Fe}^{3+}+\mathrm{Ti}^{4+}\right), \quad$ molar; $\mathrm{R} 2=$ $6 \mathrm{Ca}^{2+}+2 \mathrm{Mg}^{2+}+\mathrm{Al}^{3+}$, molar] tectonic discrimination diagram show syn- collision to post-orogeny field tectonic setting (Fig. 5b).

\section{Discussion}

The granitoids from the Chiplakot Crystalline Belt, Kumaun Himalaya, have been linked to the Columbia supercontinent subduction system in the Paleoproterozoic, according to Phukon et.al., (2018). For the Bandal and Sainj granites, Frank et.al., (1977) ascribes a whole rock $\mathrm{Rb}-\mathrm{Sr}$ age of $1840+70 \mathrm{Ma}$, demonstrating the presence of Proterozoic granitic magmatism in the Himalaya. According to Islam et.al., (2005), the Proterozoic granites of the Lesser Himalaya are rich in silica and $\mathrm{K}_{2} \mathrm{O}$, have a high $\mathrm{A} / \mathrm{CNK}$ value (>1.1), and contain normative corundum. Islam et.al., (2005) also noted that granite, granitic gneisses, and associated metasedimentaries rocks in the NW Himalaya underwent up to upper amphibolites facies metamorphism, suggesting that Proterozoic granitic gneisses were generated as basement slivers from the middle crustal level (a probable extension of the northern Indian craton). According to Singh et.al., (2009), Paleoproterozoic (ca. 1860 Ma) felsic magmatic rocks are widespread in the Lesser Himalayan Zone to the basal part of the Higher Himalayan Crystallines (HHC), implying that older crustal material exhumed due to collisional tectonics during the Himalayan orogeny was remobilized.
The Proterozoic granitoids rocks from the NW Himalaya are enriched in LREE and relatively deficient in HREE, with prominent negative $\mathrm{Eu}$ anomalies and high $\mathrm{Rb}$, Th, and $\mathrm{U}$ content, as well as negative $\mathrm{Ba}, \mathrm{Nb}, \mathrm{Sr}, \mathrm{P}$, and $\mathrm{Ti}$ anomalies (Miller et.al., 2000). The high initial $87 \mathrm{Sr} / 86 \mathrm{Sr}$ ratios (0.711-0.721) and initial epsilon $\mathrm{Nd}$ values of -5.8 to -8.8 suggest largescale reworking of Archean sialic protolith, according to the $\mathrm{Sr}$ and $\mathrm{Nd}$ isotopic properties of these rocks (Miller et.al., 2000). According to Singh (2011), granites from the Lesser and Higher Himalayas can be linked to a tectonothermal (collisional) event that occurred around 1.9-1.8 $\mathrm{Ga}$ in the Bundelkhand craton (Slabunov et.al., 2017), which is located in the southern section of the Garhwal Himalaya. Similar felsic granitic magmatism appears to occur in the Lesser Garhwal Himalaya, and more research is needed to determine whether the remobilization of Archean crust occurred in the Bundelkhand craton.

\section{Conclusion}

The collision tectonics nature of granites in Garhwal Himalaya demonstrate felsic magmatic phase implication during the Paleoproterozoic ages. The Lesser Garhwal Himalaya Toneta granites formed syncollision to the post-orogeny tectonic environment with negative $\mathrm{Eu}$ anomaly, resembling ca. 1800-1900 Ma's existing hydrothermal activity Bundelkhand craton suggest a possible linkage to it. However, the questions are still unanswered and required 
more studies to understand the nature of granitic rocks of Garhwal Himalaya whether these rocks have formed due to the melting and recrystallization of pre-existing Archean continental crust of Bundelkhand craton?

\section{Acknowledgement}

We thanks to the Prof. Y. P. Sundriyal (Former Head), Department of Geology, HNBGU, Srinagar for providing infrastructural facilities to SM and HCN. Prof. S.A. Svetov (Director, Institute of Geology, KarRC, RAS, Petrozavodsk, Russia) is acknowledged for providing laboratory facilities at Testing and Matter Analysis Centre of Karelian Research Centre, Russia. SM acknowledges DST/ INSPIRE Fellowship/ [IF160096].

\section{References}

Barker F (1979). Trondhjemite: Definition, Environment and Hypotheses of Origin. Developments in Petrology 6:1-12,

Batchelor RA and Bowden P (1985). Petrogenetic interpretation of granitoid rock series using multicationic parameters. Chem Geol 48: 43-55.

Frank W, ThoniM, Purtscheller F (1977). Geology and petrography of Kulu-South Lahul area. Colloquium International Center for Natural Research Sciences, 33, 147-172.

Gansser A (1964). Geology of the Himalayas. Wiley Inter Science, New York, 289.

Heim A and GansserA (1939). Central Himalaya, Geological observations of Swiss expedition 1936. Mem. Soc. Helv. Sci. Nat., V.73, pp. 245.
Islam R., Ahmad T, Khanna P P (2005). An overview on the granitoids of the NW Himalaya. Himalayan Geology, Vol. 26 (1), 2005, pp. 49-60.

McDonoughWFand Sun SS (1995). Composition of the Earth. Chemical Geology 120: 223-253.

Middlemost E A K (1994). Naming materials in the magma/igneous rock system. Earth Sci Rev 37: 215-224

Miller C, Klotzli U, Frank W, Thoni M, Grasemann B (2000). Proterozoic crustal evolution in the NW Himalaya (India) as recorded by circa $1.80 \mathrm{Ga}$ mafic and 1.84 $\mathrm{Ga}$ granitic magmatism. Precambrian Research, 103, 191-206.

O'Connor JT (1965). A classification for Quartz-rich igneous rocks based on feldspar ratios. U.S. Geol. Survey Prof Paper 525-B: B79-B84

Pearce J A, Harris N W, Tindle A G (1984). Trace element discrimination diagrams for the tectonic interpretation of granitic rocks. J Petrology 25: 956-983.

Phukon PJ, Sen, K, Srivastava, H.B., Singhal, S., Sen, A. (2018) U-Pb geochronology and geochemistry from the Kumaun Himalaya, NW India, reveal Paleoproterozoic arc magmatism related to formation of the Columbia supercontinent. Geological Society of America Bulletin 130, 1164-1176.

Saklani PS (1993). Geology of the Lower Himalaya (Garhwal). International Books and Periodicals Supply Service, New Delhi, 246p.

Saklani PS, Nainwal DC, Singh VK (1991). Geometry of the composite Main Central Thrust (MCT) in Yamuna valley, Garhwal Himalaya, India. N. Jb. Geol. Palaont. Mh., v. 1991, pp. 364-380.

Singh S, Jain A K, Barley M E (2009). SHRIMP U-Pb $\sim 1860$ Ma anorogenic magmatic signatures from NW Himalaya: implications for Paleoproterozoic 
assembly. In: Reddy, S.M., Mazumdar, R., Evans, D.A.D. \& Collins, A.S. (eds.) Paleoproterozoic Supercontinents and Global Evolution. The Geological Society London, Special Publicaltion, 323, 283300 .

Singh VK (2011). Structural and Metamorphic evolution of the rocks of the Garhwal Himalaya: possible linkage with Bundelkhand craton, India. Proceeding of the 2nd International Conference Precambrian Continental Growth and Tectonism (Editors: V.K. Singh \& Ram Chandra), pp. 20-35.

Singh VK and Slabunov A (2015). The Central Bundelkhand Archaean greenstone complex, Bundelkhand craton, central India: geology, composition, and geochronology of supracrustal rocks. International Geology Review, v.57, pp. 1349- 1364.

Singh VK, Singh SP, Saklani PS, Dubey CS (1998). Mesostructures and deformational history of the Central Crystallines: an example from Garhwal Himalaya, India. J. Nepal Geol. Soc., 17: pp 59-69.

Slabunov AI, Singh VK, Shchiptsov VV, Lepekhina EN, Kevlich VI (2017). A new Palaeoproterozoic (1.9-1.8 Ga) event in the crustal evolution of the Bundelkhand Craton, India: the results of (SHRIMP) Dating of zircons from giant quartz veins. In: Slabunov, A.I., Svetov, S.A., and Baltibaev, Sh.K. (eds.), Early Precambrian vs Modern Geodynamics. Extended Abstracts and Field Trips Guide. Petrozavodsk: KarRC RAS, p.239241.

Svetov S A, Stepanova A V, Chazhengina S Y, Svetova E N, Rybnikova Z P, Mikhailova A I, Paramonov A S, Utitsyna VL, Ekhova M V, Kolodey B S (2015), Precision geochemical (ICP-MS, LA-ICP-MS) analysis of rock and mineral composition: the method and accuracy estimation in the case study of Early Precambrian mafic complexes. Proceedings of the Karelian Research
Centre RAS. No 7. Precambrian Geology Series. P. 54-73.

Thakur VC (1992). Geology of western Himalaya, Pergamon Press Ltd., London, $355 \mathrm{p}$.

Valdiya KS (1980). Geology of the Kumaun Lesser Himalaya. Wadia Institute of Himalayan Geology, Dehradun, 291 p. 